\title{
SIKLUS KINERJA GURU BERBASIS SASARAN KERJA
}

\author{
Aziz Luki Akhyar \\ MIS Qomarul Hidayah Kemenag Kab. Trenggalek \\ Jl. Trenggalek-Ponorogo Km. 07, Jawa Timur \\ Email: azizahyar@gmail.com
}

\begin{abstract}
Abstrak
Penelitian bertujuan ini mengetahui manajemen kinerja guru sebagai proses kinerja berkesinambungan untuk menyamakan tujuan individu guru dan lembaga pendidikan dan rangkaian kinerja guru dari tahapan perencanaan, pelaksanaan, dan evaluasi berorientasi memenuhi standar minimal kerja agar mendapatkan kelayakan penghasilan, tunjangan, dan kenaikan jabatan atau pangkat semata yang mengakibatkan kinerja guru berkutat hal-hal yang bersifat administratif dan menyampingkan proses kinerja yang membuahkan output dan outcame sesuai tujuan lembaga pendidikan. Penelitian ini adalah penelitian kualitatif dengan pendekatan fenomologis.Teknik pengambilan data menggunakan observasi, wawancara dan dokumentasi. Analisis data meliputi analisis situs tunggal dan analisis lintas situs dengan teknik analisis data; reduksi data, penyajian data, dan simpulan. Penelitian ini menghasilkan empat temuan pokok. Pertama, tahapan prasiklus dengan persiapan penilaian dan membentuk tim penilaian kinerja guru. Kedua, tahapan perencanaan dengan fase pendefinisian, pembahasan peran, tanggung jawab, dan ekpektasi terukur. Ketiga, tahapan pembinaan dengan fase pengamatan, pemantauan, dukungan, umpan balik, dan penghargaan. Keempat tahapan siklus manajemen kinerja guru adalah evaluasi kinerja.
\end{abstract}

Kata kunci: Kinerja Guru, Siklus Kinerja, Sasaran Kerja.

\section{Pendahuluan}

Guru memiliki peran strategis dalam pendidikan dan menjadi ujung tombak dalam peningkatan kualitas layanan dan hasil pendidikan. Lahirnya Undang-undang nomor 14 tahun 2005 tentang Guru dan Dosen serta aturan terkait memberikan standardisasi guru sebagai jabatan profesi. Guru dianggap profesional apabila mampu melaksanakan tugasnya sesuai standar yang telah ditetapkan. Guru merupakan bagian yang memiliki tugas utama mendidik, mengajar, membimbing, mengarahkan, melatih, menilai, dan mengevaluasi peserta didik pada jenjang pendidikan anak usia dini jalur pendidikan formal, pendidikan 
dasar, dan pendidikan menengah. Dalam melaksanakan tugasnya, guru menerapkan keahlian, kemahiran yang memenuhi standar mutu atau norma tertentu yang diperolehnya melalui pendidikan profesi. Guru profesional dituntut memiliki keterampilan yang berdasarkan konsep dan teori ilmu pengetahuan yang mendalam, menekankan pada suatu keahlian bidang tertentu sesuai dengan bidang profesinya, tingkat pendidikan keguruan yang memadai, peka terhadap dampak kemasyarakatan dari pekerjaan yang dilaksanakannya, dan sejalan dengan dinamika kehidupan (Kunandar, 2007, P. 46).

Tanggung jawab yang dibebankan kepada guru diukur secara kualitas dan kuantitas dalam bentuk hasil kerja (A.P. Mangukenaga, 2001, P. 67). Selain itu, kinerja juga dapat diartikan sebagai suatu hasil dan usaha seseorang yang dicapai dengan adanya kemampuan dan perbuatan dalam situasi tertentu. Kinerja terkait dengan kualitas seseorang dalam melakukan pekerjaan. Kinerjaseseorangjugaberiringdengan kualitas ataupun kuantitas hasil pekerjaannya. Dalam konteks guru, kinerja sering dikaitkan dengan pertanyaan tentang hal yang dilakukan guru dikelas, untuk siswa dan sekolah, kontribusi guru yang berikan pada peserta didik dan lembaga pendidikan tempatnya bekerja. Guru yang mempunyai kinerja baik adalah guru yang profesional dan memiliki pengetahuan dan kemampuan profesi (Supriyadi, 1999, p. 70). Tentang guru yang produktif A.D. Timpe menyatakan (A.D. Timpe, 1989, p. 105) guru yang memiliki kinerja tinggi merupakan, dan ciri-cirinya; (1) memiliki kecerdasan pikir dan dapat mempelajari kondisi sekitar dengan cepat; (2) memiliki kompetensi secara profesional; (3) memiliki daya kreativitas dan inovasi yang tinggi; (4) memahami dan menguasai pekerjaan; (5) belajar dan cerdik menggunakan logika dan mengkoorganisir pekerjaan dengan efisien; (6) selalu berusaha untuk melakukan perbaikan; (7) dianggap bernilai oleh pengawas; (8) memiliki prestasi yang baik; dan (9) selalu berupaya untuk meningkatkan kemampuan diri. 
Sebagian kalangan ada yang menganggap PKG ini merupakan sebuah bentuk sanksi terhadap kemampuan guru, terutama yang sudah memiliki sertifikat profesi. Padahal, anggapan tersebut tidaklah benar. PKG dilakukan untuk meningkatkan kemampuan penguasaan kompetensi guru dan mengembangkan kinerja keprofesiannya. Selain itu, hasil dari PKG ini pun diperlukan untuk kenaikan pangkat dan golongan guru yang bersangkutan. Kinerja guru agar mencapai kondisi yang baik dan terstruktur tidak terlepas dari cara pengelolaan kinerja tersebut baik oleh atasan dan guru yang bersangkutan. Pengelolaan kinerja berhubungan dengan perencanaan, pelaksanaan, penilaian, dan evaluasi kinerja tersebut. Proses ini merupakan alur dari manajemen kinerja guru.

Kinerja guru di madrasah merupakan tanggung jawab utama dari kepala madrasah. Kepala madrasah membina gurunya agar berprestasi yang lebih baik. Kepala madrasah sebagai pimpinan di lingkungan satuan pendidikan dituntut mampu mewujudkan tujuan-tujuan yang telah ditentukan. Keberhasilan dalam mengembangkan kinerja guru sangat ditentukan oleh kepala madrasah mulai dari perencanaan, pelaksanaan, pengawasan, pengendalian, dan keselarasan seluruh sumber daya pendidikan. Tugas pokok guru adalah merencanakan pembelajaran, melaksanakan pembelajaran, evaluasi dan penilaian, melakukan perbaikan dan pengayaan pembelajaran. Sedangkan tugas pengembangan profesi guru berhubungan dengan kompetensi personal meliputi kegiatan forum ilmiah, melakukan penelitian, publikasi ilmiah, dan melaksanakan inovasi pembelajaran. Adapun tugas penunjang guru berkaitan dengan pembinaan kesiswaan, keanggotaan profesi, dan kegiatan evaluasi pembelajaran.

Bergulirnya Peraturan Kepala Badan Kepegawaian Negara Republik Indonesia Nomor 1 Tahun 2013 tentang Ketentuan Pelaksanaan Peraturan Pemerintah Nomor 46 tahun 2011 tentang Penilaian Prestasi Kerja Pegawai Negeri Sipil termasuk guru yang berstatus PNS, 
pengelolaan kinerja guru menggunakan pola Sasaran Kinerja Pegawai (SKP). Kinerja guru berdasarkan sasaran kerja pegawai tidak hanya fokus pada tugas pokok guru tetapi mencakup tiga hal yaitu kinerja guru utama sesuai tugas pokoknya, kinerja guru dalam pengembangan keprofesiannya, dan kinerja guru dalam menunjang tugas tugas pokoknya. Madrasah ibtidaiyah sebagai lembaga pendidikan di bawah naungan Kementerian Agama Republik Indonesia yang sama dengan sekolah dasar naungan Kementerian Pendidikan dan Kebudayaan Republik Indonesia. Lembaga pendidikan sebagai organisasi tentunya mempunyai sistem kerja yang mengatur tata kelola baik itu manajemen madrasah, keuangan, sarana prasarana, kurikulum dan pengelolaan proses pendidikan. Salah satu standar pendidikan adalah standar tenaga pendidik dan kependidikan yang dalam pengelolannya mencakup sistem rekrutmen, penataan tenaga pendidik sesuai kualifikasi, penataan kerja sesuai kompetensinya, penilaian kinerja, pemantauan kinerja, evaluasi kinerja, dan perbaikan kinerja dalam rangka meningkatkan kualitas tenaga pendidik di lembaga pendidikan. Madrasah ibtidaiyah sebagai lembaga pendidikan Islam yang berada di naungan kementerian agama berpedoman pada delapan standar pendidikan yang ditentukan oleh pemerintah salah satunya manajemen tenaga pendidik dan tenaga pendidikan.

Peraturan Badan Kepegawaian Negara tentang prestasi kerja pegawai diterapkan di semua instansi pemerintahan. Demikian halnya kementerian agama menerapkannya bagi pegawai struktural maupun fungsional termasuk diantaran guru pegawai negeri sipil. Madrasah ibtidaiyah negeri adalah lembaga pendidikan yang diselenggarakan oleh pemerintah dan dibawah binaan Kementerian Agama Republik Indonesia. Di Kabupaten Trenggalek madrasah ibtidaiyah negeri hanya dua lembaga yakni MI Negeri 1 dan MI Negeri 2 Trenggalek. Madrasah Ibtidaiyah Negeri 1 Trenggalek dan berstatus negeri yang pertama di Kabupaten 
Trenggalek dengan jumlah siswa saat ini sebanyak 537 orang, tenaga pendidik 33 orang, dan 5 orang tenaga administrasi. Madrasah ini menerapkan penilaian kinerja pegawainya berdasarkan sasaran kerja pegawai. Pengelolaan kerja pegawai di MI Negeri 1 Trenggalek melalui tahapan perencanaan diawal tahun, pengamatan, dan penilaian di akhir tahun.

Sistem pengelolaan kinerja guru di MI Negeri Trenggalek dalam penataan guru dan kerjanya menggunakan acuan kinerja berdasarkan sasaran kinerja pegawai yang telah ditetapkan oleh pemerintah sebagai sarana pencapaian prestasi kerja pegawai. Untuk menyikapi hal tersebut kepala madrasah telah membentuk tim penilaian kinerja guru dan tim pengembangan keprofesian berkelanjutan yang dituangkan dalam surat keputusan kepala madrasah. Tim ini bertugas mengoordinasi tata kerja guru mulai dari penyusunan formulir kerja, pengukuran kinerja, penilaian kinerja, merencanakan dan melaksanakan kegiatan pengembangan bagi guru yang masih mengalami kekurangan aspek kinerja, selain itu serta pengembangan terbuka bagi guru yang berkeinginan menambah khasanah keilmuaan. PKG (Penilaian kinerja guru) berorientasi pada kewajiban guru dalam melaksanakan tugasnya dengan proses penilaian dalam bentuk formatif dan sumatif dalam bentuk kompetensi guru. Sedangkan penilaian kinerja guru dengan pola Sasaran Kerja Pegawai berorientasi pada kewajiban setiap guru PNS dengan bentuk penilaian protofolio dan dapat ditagih serta dilaksanakan pada akhir tahun.

Manajemen kinerja adalah proses sistematis untuk memperbaiki kinerja organisasi dengan mengembangkan kinerja individu dan tim sebagai sarana untuk mendapatkan hasil lebih baik dengan memahami dan mengelola kinerja dalam kerangka kerja yang disepakati tentang tujuan terencana, standar dan persyaratan kompetensi. Siklus manajemen kinerja adalah squence atau urutan proses kinerja dan aktivitas yang dilakukan secara berurutan dan berkelanjutan dengan muara pencapaian 
hasil (kinerja) yang diharapkan. Menurut Amstrong (M Amstrong, 2009, p. 12) manajemen kinerja adalah "Performance management can be defined as systematic process improving organizational by developing the performance individuals and teams. It is a mean of getting result from organization, temas and individuals by unsderstanding and managing performance within an a agreed frame work of planned goal, standard an ccompetence requirements."

Kinerja adalah hasil kerja secara kualitas dan kuantitas yang dicapai oleh seorang pegawai dalam melaksanakan tugasnya sesuai dengan tanggung jawab yang diberikan kepadanya. Kinerja guru dimaknai hasil kerja secara kualitas dan kuantitas yang dicapai guru dalam tugasya sesuai tanggung jawab dan fungsinya. Perbaikan kinerja adalah proses tranformasi kondisi kinerja saat ini menuju pada keadaan kondisi kinerja yang lebih baik di masa yang akan datang (Wibowo, ,2014, p. 243).

Langkah-langkah perbaikan kinerja guru adalah proses perbaikan kinerja guru untuk peningkatan kondisi kinerja yang lebih baik. Proses perbaikan kinerja guru dilakukan dengan pengembangan keprofesian berkelanjutan dan pelatihan (Continous Professional Development) untuk mengupgrade kinerja guru dengan maksud tercapainya peningkatan profesionalisme guru.

Berdasarkan berbagai paparan di atas manajemen kinerja sebagai rangkaian kinerja baik itu organisasi, kelompok, maupun individu dengan berbagai upaya peningkatan agar mencapai tujuan organisasi yang telah ditetapkan sebelumnya dalam kurun waktu tertentu. Manajemen kinerja sangat diperlukan dalam rangka memenuhi standar hasil yang telah ditentukan organisasi melalui performance organisasi tersebut. Berkaitan dengan kinerja guru manajemen kinerja diartikan suatu proses manajemen yang dirancang untuk menghubungkan tujuan organisasi dengan kepentingan-kepentingan individu guru sehingga bisa untuk memastikan bahwa antara tujuan individu guru dan sekolah sama. Dalam 
hal ini manajemen kinerja guru berorientasi pada cara mengelola pekerjaan guru untuk mencapai target dan hasil yang diharapkan lembaga pendidikan.

Manajemen kinerja guru berkaitan erat dengan pelaksanaan kerjanya di sekolah atau madrasah. Guru menjalankan tugasnya sebagai bentuk tanggung jawab baik itu dari segi kuantitas maupun kualitas. Tugas guru mencakup pembuatan perencanaan pembelajaran, pembelajaran di kelas, penilaian dan evaluasi, serta langkah perbaikan dan pengayaan hasil evaluasi belajar siswa. Keberhasilan guru dalam melaksanakan tugas dan peran profesinya merupakan ukuran kinerja yang dicapai. Hal ini menunjukkan etos kerja dan integritas guru sesuai profesionalisme yang dipikulnya. Manajemen kinerja sebagai proses terintegrasi yang menyatukan power dan mendukung kinerja organisasi dengan pengelolaan tenaga kerja. Manfaat manajemen kinerja berorientasi peningkatan kinerja individu dan organisasi secara bertahap dalam menginventarisir kemampuan dan reward non finansial bagi staf, mengusahakan dasar untuk membantu pegawai yang kinerjanya rendah, digunakan untuk mengembangkan individu, mendukung kepemimpinan atasan, proses motivasi dan sirkulasi ulang kegiatan kinerja (Amstrong, 2006, p. 11).

Berkaitan dengan siklus manajemen kinerja Seeker dan Wilson (Karen R Seeker dan Joe B Wilson, 2000, p. 5) menyebutkan bahwa siklus manejemen kinerja mencakup tahapan-tahapan yaitu penyusunan rancangan kerja, pengawasan dan pengarahan, serta penilaian. Tahapan rancangan kerja meliputi penentuan tugas, penjelasan posisi karyawan, kesedian bekerja dan pengukuran kemampuan. Tahapan pengawasan meliputi pengamatan, pemantauan proses kinerja, pembimbingan dan pengarahan, memberikan motivasi dan respon balik pimpinan. Tahapan penilaian meliputi mengukur hasil kerja yang dicapai dan penataan mekenisme kerja tahun berikutnya secara berulang-ulang. 


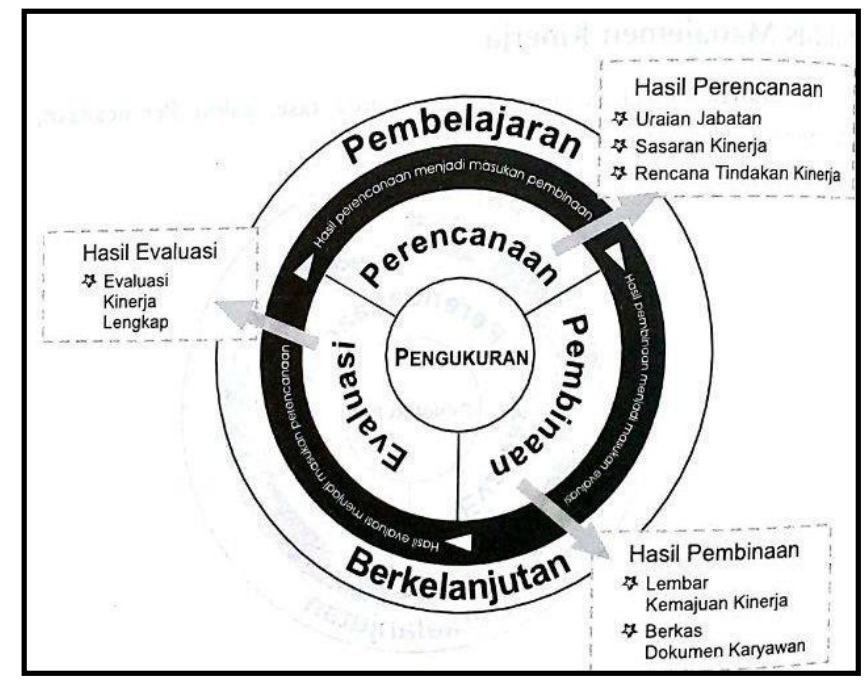

Sumber: (Ramelan, 2000, p. 5)

Manajemen kinerja berkepentingan dengan setiap orang yang terlibat dalam organisasi, tidak sebatas kebutuhan pimpinan saja. Proses manajemen kinerja dengan pendekatan holistik untuk mengelola kinerja menjadi kepentingan setiap orang dalam organisasi tetapi tidak menjadi praktik menyeluruh. Manajemen kinerja berkaitan dengan komitmen pekerja dengan masalah pengelolaan sumber daya organisasi sebagai input, proses pelaksanaan, hasil kinerja, dan dampak dari kinerja.

\section{Permasalahan}

\section{Manajemen Mutu Pendidikan}

Fase perencanaan sebagai bentuk kesepakatan antara pekerja dan manajer bekerja sama merencanakan hal yang harus dilakukan pekerja dalam setahun mendatang, mendefinisikan bagaimana kinerja harus diukur, mengidentifikasi dan merencanakan mengatasi hambatan dan mendapatkan saling pengertian tentang pekerjaan (Wibowo, 2014, p. 58)

Rancangan kerja menjadi dasar bagi pimpinan dan bawahan dalam mengimplemnatsikan kinerja di organisasi. Pelaksanaan merupakan implementasi dari perencanaan dalam bentuk kegiatan nyata. Selama 
proses pelaksanaan seorang manajer mempunyai tugas penting untuk menggerakkan para anggotanya.

Thomas S. Bateman and Scott A. Snell menyatakan bahwa langkah-langkah dalam membuat sebuah perencanaan yang baik yakni pertama adalah situational analysis, dilanjutkan kedua dengan alternative goals and plans, langkah yang selanjutnya adalah goal and plan evaluation, tahap yang keempat goal and plan selection, dan diakhiri dengan implementation ( Thomas S. Bateman and Scott A. Snell, e 7, p. 118-121). Kesepakatan kerja atau disebut juga perjanjian kerja menetapkan pengharapan pekerjaan yang harus dilakukan, hasil yang dicapai dan atribut serta kompetensi yang diperlukan untuk mencapai hasil tersebut.

Dharma menyebutkan Aspek harapan kinerja sangat menentukan dalam membuat kesepakatan kinerja mencakup (a) uraian pekerjaan harus dilakukan dalam bentuk key result area, (b) sasaran dan standar kinerja, (c) ukuran dan indikator kinerja, (d) atribut dan kompetensi, dan (e) persyaratan dan nilai dasar organisasi (Surya Dharma, 2013, p. 68).

Model perencanaan individual mengembangkan rencana kerja masing-masing anggota dengan mempertimbangkan ketrampilan, pengetahuan, dan kemampuan yang dimiliki. Rencana kerja tersebut juga merinci tanggung jawab masing-masing anggota yang dibutuhkan untuk mencapai sasaran dan teknik kelompok kerja.

Komponen rencana kerja individual mencakup uraian jabatan, sasaran kerja, dan rencana tindakan kinerja. ( Karen R Seeker dan Joe B Wilson, 2000, p. 12).

\section{Pembinaan}

Pembinaan merupakan proses pengawasan, pengamatan, dan pemantauan kinerja bawahan sesuai tugasnya masing-masing (Ivancevich,2008,p.46). Dalam siklus manajemen kinerja fase pembinaan guru dibimbing dan dikembangkan serta mendorong atau mengarahkan upaya mereka melalui dukungan, umpan balik, dan penghargaan. 
Kesepakatan rancangan kerja antara pimpinan dan bawahan merupakan implementasi dari perencanaan dalam bentuk kegiatan nyata. Selama proses pelaksanaan seorang manajer mempunyai tugas penting untuk menggerakkan para anggotanya.

Pembinaan menurut Malthis (Malthis, R.L \& Jackson, 2001, p.112) sebagai bentuk tahapan pencapaian tujuan organisasi melalui kompetensikompetensi tertentu setiap individu yang ada diorganisasi, sehingga pengawasan dalam rangka pembinaan menjadi hal yang petning dilakukan demi terlaksananya tujuan organisasi baik pengawasan secara khusus maupun umum.

Pengarahan merupakan upaya untuk menciptakan suasana kerja dinamis, yang sehat agar pelaksanaan kinerja lebih efektif dan efisien. Beberapa kegiatan pada fungsi pengarahan:membimbing dan memberi motivasi kepada pekerja agar dapat bekerja secara efektif dan efisien, memberi tugas serta penjelasan secara rutin tentang pekerjaan, dan menjelaskan semua kebijakan yang sudah ditetapkan.

Pembinaan menjadi rangkaian yang berkesinambungan dalam kinerja sebagai proses perbaikan dan peningkatan kerja pegawai. Selanjutnya Pembinaan merupakan tahapan mengembangkan dan memberikan motivasi kerja pegawai dalam mencapai kinerja puncaknya. Pembinaan adalah bagian dari siklus berkelanjutan dari perencanaan, pembinaan, evaluasi, dan pengukuran kinerja dalam aktivitas sistem manajemen kinerja yang terus bergulir setiap tahun secara siklus yang menjadi ajang pembelajaran berkelanjutan oleh semua SDM organisasi. Pembinaan (coaching) adalah upaya berharga untuk membantu orang lain mencapai kinerja tinggi.( Bill Foster dan Karen R.Seeker, 2001, p.1).

Bill Foster dan Karen R.Seeker, menyatakan ada empat hal yang menjadi bagian dari model pembinaan karyawan menjadi tanggung jawab seorang pimpinan; (1) memantau kinerja karyawan. langkah pertama ini manajer menggunakan bahanbahan hasil perencanaan yang meliputi: 
deskripsi jabatan karyawan, sasaran kinerja, dan rencana tindakan kinerja untuk mengetahui peran, tanggung jawab, tindakan, dan pengukuran yang telah disepakati antara manajer dengan karyawan yang menjadi basis penentuan kinerja tahun itu. Manajer dengan menggunakaan bahanbahan ini mengamati kinerja karyawan, dan kemudian mendokumentasikan perilaku yang mengindikasikan keberhasilan atau kegagalan dalam menjalankan kewajibannya. (2) mendiagnosis kebutuhan perbaikan kinerja, dengan memantau perilaku karyawan manajer dapat menilai apakah perilaku karyawan memenuhi sasaran kinerja, melebihi, atau tidak memenuhi harapan. Jika perilaku karyawan tidak memenuhi harapan konteks ini biasanya muncul dalam empat bidang, yaitu pengetahuan, keterampilan, motivasi, dan kepercayaan diri. Empat bidang ini merupakan faktor yang membentuk kompetensi seorang karyawan. (3) menetapkan cara untuk memperbaiki situasi. Setelah tuntutan perbaikan kinerja diidentifikasikan, manajer perlu menetapkan jenis arahan atau dukungan dan kemudian menentukan apa yang diperlukan karyawan. Misalnya apa yang harus dilakukan karyawan, bagaimana cara melakukannya, dan kapan harus dilakukan. Dalam konteks ini lebih baik manajer menentukan apa yang diperlukan karyawan itu dibicarakan bersama karyawan yang bersangkutan. (4) menyampaikan umpan balik yang konstruktif. Memberi umpan balik (feedback) merupakan proses yang terus menerus dan berkelanjutan. Oleh karena itu harus dipersiapkan dan disampaikan secara konstruktif dan hati-hati, agar umpan balik (feedback) itu dapat dipahami oleh karyawan yang bersangkutan. Yang sangat penting diupayakan sedapatnya arahan atau dukungan manajer terhadap karyawan itu dapat membantu karyawan atau tidak. Jika berhasil membantu karyawan maka hargailah upaya karyawan memperbaiki kinerja itu dan rayakan bersamanya. (Bill Foster dan Karen R.Seeker, 2001, p.12). 
Organisasi pendidikan berusaha membangun kinerja melalui peningkatan kompetensi karyawan, pemberdayaan karyawan, pemberian kompensasi yang seimbang dan proporsional, dan pembinaan karyawan yang terprogram dan berkelanjutan melalui pemantauan kinerja, mendiagnosis kebutuhan perbaikan, menetapkan cara memperbaiki, dan menyampaikan umpan balik yang konstruktif yang bermuara pada peningkatan kinerja karyawan dan organisasi. Komunikasi kepala sekolah dan guru sebagai bentuk pembinaan dan bekerja sama untuk saling berbagi informasi mengenai pemecahan masalah, peningkatan dan kemajuan kinerja, dan faktor-faktor yang kurang mendukung kinerja. Keterampilan menemukan dan mengatasi masalah merupakan hal penting dari komunikasi yang dibangun oleh kepala sekolah.

\section{Tahapan Evaluasi}

Untuk mengetahui efektifitas dan efisiensi suatu rencana pengelola harus melakukan evaluasi. Evaluasi kinerja merupakan proses mengevaluasi pekerja pada berbagai dimensi yang berkaitan dengan pekerjaan. (John W. Newstrom dan Keith Davis, 1997, p. 175). Evaluasi kinerja merupakan proses mengevaluasi pekerja pada berbagai dimensi yang berkaitan dengan pekerjaan. Evaluasi kinerja menilai dan mengevaluasi kinerja perorangan dan menjadi tahapan yang penting sistem kinerja.

Pimpinan memperoleh data dan capaian kinerja bawahan dapat melalui penilaian diri sendiri dan penilaian atasan. Agar evaluasi kinerja mendapatkan hasil yang baik, pemimpin melakukan review karena hal tersebut bisa menjadi gambaran akan kondisi kinerja pegawai sehingga dapat menjadi salah satu informasi untuk penilaian kinerja. Implikasi evaluasi kinerja meliputi evaluasi sasaran dan tujuan, evaluasi rencana kinerja, evaluasi lingkungan kerja, evaluasi proses kinerja, evaluasi pengukuran kinerja, dan evaluasi hasil.( Robert Kreitner dan Angelo Kinicki, 2010, p. 300). Hasil kinerja bawahan dapat dilihat ddari hasil 
penilaian yang dieproleh selama kegiatan berlangsung. Pembinaan penilaiaan dilaksanakan diakhir kegiatan berdasarkan waktu yang telah ditentukan. Penilaian yang dilakukan berfungsi mengetahui tingkat kemampuan karyawan, dalam hal ini guru. Selain itu untuk menunjukkan tingkat kerjasama antara guru, atasan, dan lembaga pendidikan. Penilaian yang telah dilaksanakan menjadi dasar untuk menentukan langkahlangkah perbaikan dan pengembangan kinerja guru.

Sasaran Kerja Pegawai (SKP) merupakan target kerja yang akan dilakukan oleh PNS selama satu tahun. SKP sebagai bentuk kontrak kerja antara PNS dengan atasan langsung. Atas dasar SKP yang telah dibuat sendiri oleh PNS dan disetujui oleh atasan langsung sebagai penilai, selanjutnya atasan langsung dapat menilai prestasi kerja pegawai, dengan membandingkan target atau kontrak kerja dalam SKP dengan realita pekerjaan yang telah dicapai dalam satu tahun. Sasaran kerja pegawai adalah suatu pernyataan tertulis dari pekerja atau employer tentang kinerja yang harus dicapai dengan menuangkan perencanaan kinerja dengan orientasi output yang berbanding dengan perencanaan kinerja dari dirinya sendiri. Sasaran kerja individu merupakan pernyataan individu dalam bidang kerjanya dengan orientasi target hasil yang akan dicapainya. Dedi menyatakan bahwa komponen sasaran kerja individu mencakup uraian bidang tugas yang akan dilaksanakan, tipe pekerjaan (kuantitas dan kualitas standar kerja), waktu pencapaian dan hasil pekerjaan yang ditargetkan berbanding dengan tipe pekerjaan tersebut, serta waktu dan biaya penyelesaian kerja tersebut (Dedi Rianto Rahadi, 2010, p.116).

Indikator sasaran kerja individu guru berdasarkan peraturan menteri pendayagunaan aparatur Negara dan birokarasi nomor 16 tahun 2009 tentang jabatan fungsional guru dan angka kreditnya mencakup tiga hal; 1) tugas pembelajaran, 2) pengembangan keprofesian, dan 3) penunjang kegiatan belajar mengajar. Rancangan penilaian kinerja 
pegawai dalam konteks ini adalah individu guru yang tidak terlepas dari standar kompetensi guru. Rancangan sistem penilaian kinerja individu dengan proses; (a) awal tahun kerja atau kalender kerja setiap instansi/lembaga pendidikan merencanakan sasaran kinerja dengan membuat kontrak kerja yang telah disepakati oleh individu dan atasanya. (b) isian kontrak kerja dipantau dan dinilai paruh waktu awal tahun kerja dengan sistem penilaian formatif dan akhir waktu kalender kerja dengan penilaian sumatif. (c) kontrak kerja diamati dan dipantau dengan dua tahap yakni tahap formatif dan tahap sumatif. (d) penilaian kinerja dengan membandingkan isian perencanaan individu tiap item uraian tugas yang direncanakan dengan hasil fisik yang dicapai pada masa penilaian kalender kerja, kemudian memberikan skoring hasil kerja dengan predikat penilaian sesuai standar yang telah disepakati dan ditentukan oleh organisasinya. (e) pernyataan hasil kinerja dituang dalam bentuk penilaian dengan menuangkan nilai tiap item kinerja dan memberikan predikat atau kualifikasi hasil yang dicapai. (f) akhir penilaian, ada evaluasi kekurangan individu yang memberikan tuntutan individu untuk mengikuti kegiatan peningkatan, pemberdayaan dan pengembangan kinerja individu masingmasing sehingga periodik kedepan hal-hal perbaikan dapat memenuhi target yang telah direncanakan.

Penilaian Kinerja Guru (PKG) merupakan proses analisis dan penilaian pelaksanaan dan hasil kerja guru dalam menjalankan peran dan fungsi secara pprofesional. PKG menjadi dasar untuk penetapan angka kredit bagi guru durasi satu tahun kinerja dan modal untuk pengembangan keprofesian berkelanjutan bagi guru sesuai hasil penilaian. Waktu penilaian untuk kegiatan PKG ada dua yaitu penilaian formatif (awal) dan penilaian sumatif (akhir tahun). Aspek PKG mencakup setiap butir kegiatan tugas utama dalam pembinaan karir, pangkat dan jabatannya. 
Sedangkan sasaran kerja pegawai bagi guru merupakan rencana kerja dan target yang akan dicapai oleh guru PNS yang disusun dan disepakati bersama antara pegawai dengan atasan langsung pegawai. SKP dibuat di awal tahun yakni bulan Januari dan jika sudah disetujui oleh atasan dengan bentuk lembar sasaran final maka selanjutnya akan ditetapkan untuk diukur dalam kurun waktu satu tahun dan dinilai diakhir tahun yakni bulan Desember tahun tersebut. SKP sifatnya wajib bagi PNS yang termasuk didalamnya guru PNS, jika guru terbukti tidak membuat SKP akan dijatuhi sanksi sesuai ketentuan yang berlaku. Penilaian SKP mencakup aspek kuantitas, kualitas, waktu, dan biaya sesuai karakteristik tugas PNS yang bersangkutan. Apabila PNS itu adalah guru, keempat aspek tersebut menyesuaikan sesuai tugasnya sebagai guru.

\section{Metodologi}

Jenis penelitian ini adalah kualitatif yang mengadopsi model Miles \& Huberman (1994, p. 10). Penelitian dilakukan di Madrasah Ibtidaiyah Negeri kabupaten Trenggalek sebagai lokasi penelitiannya. Objek penelitiannya fokus pada madrasah ibtidaiyah negeri di daerah tersebut. Madrasah yang di-maksud adalah MIN 1 dan MIN 2 Trenggalek. Penelitian dilakukan selama kurang lebih empat bulan, mulai 05 Spetember sampai 27 Desember 2017.

Unit analisis yang digunakan dalam penelitian ini adalah kelembagaan. Mengingat penelitian ini difokuskan pada guru Madrasah Itbidaiyah Negeri Trenggalek, secara detail analisisnya adalah pelaksanaan tugas dan fungsi guru pada 2 madrasah negeri di daerah tersebut.

Sumber data utama dalam penelitian ini adalah kata-kata dan tindakan kepala sekolah dan guru di Madrasah Itbidaiyah Negeri Trenggalek. Data akan dihimpun melalui observasi, wawancara, dan studi pustaka yang terkait dengan pelaksanaan tugas guru. Selain itu, 
diperlukan juga data dari pengawas madrasah sebagai data tambahan yang mampu memberikan gambaran tentang pelaksanaan tugas guru di madrasah menengah negeri tersebut.

Pengukuran keabsahan data dilakukan dengan trianggulasi yakni untuk melakukan validasi terhadap data-data peneliti-an yang telah didapatkan di lapangan. Analisis data dilakukan dengan pro-ses mencari dan menyusun secara sistema-tis data yang diperoleh dari hasil wawancara, catatan lapangan, dan bahan-bahan lain, sehingga dapat mudah dipahami, dan temuannya dapat diinformasikan kepada orang lain (Sugiyono, 2015, p. 334).

\section{Pembahasan}

Siklus manajemen kinerja di Madrasah Ibtidaiyah Negeri 1 dan 2 Trenggalek menggunakan fase perencanaan (pendefinisian, pembahasan peran, tanggung jawab dan ekpektasi terukur), fase pembinaan (pengamatan, dukungan, umpan balik dan penghargaan), dan fase evaluasi.

\section{Tahapan perencanaan}

Perencanaan kinerja guru berbasis sasaran kerja pegawai yang dapat teramati pada situs MI Negeri 1 Trenggalek adalah penataan tugas guru, menentukan target capaian guru, komunikasi atasan dan bawahan prapenetapan capaian, dan tanggung jawab moral guru. Penataan tugas guru menggunakan standar operasional proses yang menjadi pedoman dalam menentukan posisi jabatan dan tugas yang diampu guru, tandar penentuan tugas dan beban mengajar guru mensyaratkan alokasi kebutuhan guru berdasarkan rasio siswa, kesesuaian kualifikasi pendidikan guru dengan bidang yang diampunya dengan patokan guru yang sudah bersertifkat pendidik dinyatakan sesuai atau linier walaupun kualifikasi pendidikan guru tidak sesuai dengan bidang yang diampu, dan status kelayakan diterima oleh sistem pendataan SIMPATIKA Kementerian Agama, guru yang memenuhi syarat berhak melaksanakan 
tugasnya sesuai alokasi bidang guru kelas, guru mata pelajaran Pendidikan Agama Islam, Bidang Studi Matematika, Pendidikan Olah Raga, dan Bidang Studi Bahasa Arab. Status layak sistem simpatika sangat diutamakan karena status ini berhubungan dengan kesejahteraan guru berupa tunjangan profesi.

Pembahasan peran guru dalam bentuk penentuan target capaian kinerja dalam satu tahun dengan menuliskan rencana kerja pada lembar Sasaran Kerja pegawai setiap bulan Januari. Guru diberikan rambu-rambu penyusunan target minimal dalam 1 (satu) tahun penilaian dan penyusunan target kinerja sesuai kebutuhan angka kredit guru pada tahun tersebut. Tanggung jawab secara moral menjadi dasar penyusunan rencana kerja tidak hanya sekadar mengugurkan kewajiban tetapi ada tuntutan individu guru untuk memenuhi target yang telah ditentukannya sendiri.

Komunikasi dua arah antara atasan dan guru diterapkan sebelum pengesahan lembar sasaran kerja yang bertujuan mengukur diri sendiri bagi guru menggunakan evaluasi diri sehingga guru diharapkan dapat memenuhi target kinerja dengan baik dan sesuai rencana kinerja. Komunikasi dilaksanakan secara tertutup khusus guru yang bersangkutan dengan pimpinan sehingga guru diberi ruang kebebasan untuk menyampaikan rencana kerjanya dan kendala yang dihadapinya. Tujuan evaluasi diri sebelum pengesahan lembar kerja dilakukan untuk menghindari praktik sangat baik dalam perencanaan tetapi tidak terealisasi. Sedangkan pada situs MI Negeri 2 Trenggalek perencanaan kinerja ini hampir sama dengan MI Negeri 1 Trenggalek, yakni penentuan tugas dan peran guru menggunakan aturan dan sistem simpatika kelayakan tunjangan menjadi dasar utama, pembahasan peran dengan penentuan target capaian kinerja setiap awal dan adanya evaluasi diri guru sebelum rencana capaian disahkan oleh pimpinan. 


\section{Pembinaan}

Pembinaan kinerja guru berbasis Sasaran Kerja Pegawai yang diamati di MI Negeri 1 Trenggalek adalah pengamatan kinerja, dukungan, umpan balik, dan penghargaan. Pengamatan kinerja sebagai proses penilaian kinerja guru menggunakan rujukan lembar sasaran kerja pegawai yang telah disusun awal tahun. Penilaian kinerja tugas utama guru mencakup kompetensi pedagogik, kompetensi kepribadian, kompetensi sosial, dan kompetensi profesional. Empat komponen tersebut di breakdown ke dalam 14 kompetensi penilaian kinerja guru meliputi kemampuan karakteristik peserta didik, kemampuan tentang teori belajar dan prinsipprinsip pembelajaran yang mendidik, kemampuan pengembangan kurikulum, kemampuan pembelajaran yang mendidik, kemampuan pengembangan potensi peserta didik, kemampuan komunikasi dengan peserta didik, kemampuan menilai dan mengevaluasi, kemampuan bertindak sesuai dengan norma agama, hukum, sosial dan kebudayaan nasional, menunjukkan pribadi yang dewasa dan teladan, etos kerja, tanggung jawab yang tinggi, rasa bangga menjadi guru, bersikap inklusif, bertindak obyektif, serta tidak diskriminatif, komunikasi dengan sesama guru, tenaga kependidikan, orang tua, peserta didik, dan masyarakat, kemampuan penguasaan materi, struktur, konsep dan pola pikir keilmuan yang mendukung mata pelajaran yang diampu, dan kemampuan mengembangkan keprofesionalan melalui tindakan yang reflektif.

Dalam proses pegamatan kinerja menggunakan instrumen dan indikator pengamatan sebelum, proses, dan setelah pengamatan. Proses pengamatan dilaksanakan oleh tim penilaian kinerja guru dengan menggunakan pendekatan langsung ke dalam kelas ketik proses pembelajaran, wawancara dengan guru, dan pemeriksaan kelengkapan dokumen yang dimiliki oleh guru. Penilaian kinerja guru berbasis SKP dilaksanakan dua tahap yaitu tahap formatif (Januari-Juni) dan tahap 
formatif (Juli-Desember) yang hasilnya di gabungkan menjadi nilai akhir kinerja pada bulan Desember. Apabila di akhir penilaian guru ada yang belum memenuhi target sesuai rencananya secara otomatis nilai capaiannya akan turun ke predikat dibawahnya atau kurang. Hal yang menyebabkan guru mengalami kesulitan memenuhi capaian targetnya disebabkan penyesuaian kurikulum baru yang berkaitan dengan perencanaan pembelajaran, administrasi pembelajaran, dan penilaian dalam proses adaptasi, serta guru masih kesulitan dalam membuat karya tulis dan karya inovatif.

Dukungan yang diberikan untuk menyikapi kekurangan tersebut tim penilaian kinerja melaksanakan forum konsultasi individu dan konsultasi kelompok sesuai subtansi permasalahanya. Adanya kegiatan pertemuan mingguan sebagai wahana komunikasi antara guru dan atasan yang dilaksanakan mulai hari senin sampai kamis setiap jam pulang siswa sampai batas akhir jam kerja. Materi yang diangkat tentang subtansi rencana pembelajaran, penilaian, karya tulis, da karya inovatif yang di pandu langsung oleh tim penilai kinerja guru MI Negeri 1 Trenggalek. Upaya umpan balik dalam bentuk penghargaan bagi guru yang berprestasi kinerjanya madrasah memberikan peenghargaan tertulis, bantuana studi lanjut, dan assesement promosi jabatan. Sedangkan situs 2 MI Negeri 2 Trenggalek, pembinaan kinerja ini hampir sama dengan MI Negeri 1 Trenggalek yakni pengamatan atau proses penilaian kinerja menggunakan dua tahap, tahap formatif, da tahap sumatif yang hasilnya di gabung menjadi nilai akhir pada bulan Desember, pelaksana penilaian kinerja adalah tim penilai yang ditetapkan oleh kepala madrasah, prosedur pengamatan menggunakan instrummen dan indikator baik sebelum, pada proses, dan sesudah pengamatan. MI Negeri 2 Trenggalek memberikan dukungan kepada guru yang menggalami kesulitan dalam forum konsultasi individu dan belum melaksanakan kegiatan mingguan untuk konsultasi secara kelompok persepktif permasalahan yang dihadapi 
guru. Dukungan dalam bentuk penghargaan masih dalam penghargaan tertulis, dan promosi jabatan melalui sistem assesment oleh kementerian agama, belum mempunyai program penghargaan dalam bentuk bantuan biaya studi lanjutan.

\section{Evaluasi Kinerja}

Evaluasi kerja sebagai puncak penilaian kinerja, evaluasi kerja berbasis SKP yang teramati di MI Negeri 1 Trenggalek dilaksanakan pada bulan Desember. Setiap guru mengumpulkan berkas fisik sesuai lembar sasaran kerja masing-masing berupa bukti fisik tugas utama guru, bukti fisik pengembangan diri, bukti fisik publikasi ilmiah, dan bukti fisi pendukung lainnya. Tim penilai melakukan analisis bukti fisik yang dikumpulkan dan memberikan penilaian dalam bentuk lembar hasil penilaian kinerja guru dan perolehan angka kredit kinerja tugas utama guru. Hasil penilaian kinerja guru tugas utama di masukkan ke lembar capaian hasil SKP dengan menyebutkan nilai angka kredit, mutu capaian, dan kuantitas berkas yang dicapai.

Sedangkan penilaian pengembangan diri, publikasi ilmiah, karya inovatif, dan tugas pendukung lainnya mengacu pada pedoman penilaian yang ditentukan oleh madrasah dan hasilnya dituangkan dalam lembar pengkuran capaian kinerja dengan menyebutkan kuantitas yang dicapai, hasil angka kreditnya, dan mutu capaiannya. Seluruh hasil penilaian tugas utama guru, pengembangan diri, publikasi ilmiah, karya inovatif, dan tugas pendukung lainnya diterbitkan dalam bentuk lembar pengukuran capaian sasaran kerja yang disahkan oleh atasan. Perbaikan kinerja merupakan program penyusunan kegiatan perbaikan yang diperlukan oleh guru MI Negeri 1 Trenggalek sesuai hasil analisa penilaian kinerja guru, dan program perbaikan menjadi agenda kegiatan tahun berikutnya.

Pada MI Negeri 2 Trenggalek, evaluasi kinerja dan perbaikan kerja hampir sama dengan MI Negeri 1 Trenggalek yakni bulan Desember 
mengumpulkan seluruh berkas fisik mulai dari tugas utama guru, pengembangan diri, publikasi ilmiah, karya inovatif, dan pendukung lainnya yang akan dianalisa dan dinilai oleh tim penilaian kinerja guru tingkat madrasah dan hasil pengukuran capaiannya diterbitkan dalam bentuk lembar pengukuran sasaran kerja pegawai dan disahkan oleh atasan. Penyusunan program perbaikan kinerj hampir sama dengan MI Negeri 1 Trenggalek yakni menyusun program perbaikan yang dibutuhkan dengan menyesuaikan anggaran madrasah.

Tim penilai kinerja guru dan pengembangan keprofesian berkelanjutan yang dilegalisasikan kepala madrasah sebagai tim kerja di 1 MI Negeri 1 Trenggalek dan MI Negeri 2 Trenggalek memegang peran dalam efektifitas proses manajemen kinerja guru mulai fase perencanaan, pembinaan, dan evaluasi. Tim PKG dan PKG menjadi pelaksana tugas kepala madrasah sebagai evaluator tugas guru dengan basis Sasaran Kerja Pegawai yang berdampak pada peningkatan kinerja guru. Disamping itu komunikasi yang dibangun antara pimpinan dan guru di situs 1 MI Negeri 1 Trenggalek dan situs 2 MI Negeri 2 Trenggalek melalui tim PKG dan PKB lebih terbuka dan terciptanya iklim kinerja yang harmonis dan saling membantu kekurangan antara satu guru dengan guru lainnya.

\section{Kesimpulan}

Berdasarkan deskripsi dan dan ana-lisis data hasil wawancara, hasil pengamatan dan studi dokumen dapat disimpulkan bahwa siklus manajemen kinerja guru berbasis sasaran kerja pegawai dengan tahapan (1) pra siklus (persiapan), (2) perencanaan (3) pembinan (4) evaluasi mewujudkan efektifnya manajemen kinerja guru. Hasil penelitian ini menguatkan dan mendukung teori siklus manajemen kinerja Seeker dan Wilson bahwa manajemen kinerja melalui tiga siklus, yaitu (1) tahap perencanaan melalui fase pendefinisian, fase pembahasan peran, fase ekspektasi, dan fase pembahasan tanggung jawab, (2) tahap pembinaan 
melalui fase pengamatan, fase pemantauan, fase dukungan, fase umpan balik, dan fase penghargaan, dan (3) tahap evaluasi melalui fase evaluasi kerja dan fase pengembangan kerja. Dalam penelitian ini juga menemukan indikasi peran penting tim penilai kineja guru yang bertugas mendampingi, menfasilitasi, mengamati, memantau, menilai dan membangun komunikasi efektif dua arah guru dan pimpinan selama manajemen kinerja guru dilaksanakan. Dalam manajemen kinerja guru, kepala madrasah mempunyai peran penting dalam regulasi sistem kinerja guru di lembaga pendidikan.

\section{Daftar Pustaka}

Amstrong, Mechael, 2006, Performance Management Key Strategies and Practical Guidelines, London: Koganpage, Third Edition.

Kogan Page. 2009, Handbook of perfonmance Management, London:

Kreitner, et.al, 2010, Organizational behavior, NewYork: McGraw-Hill.

Rahadi, Rianto Dedi, 2010, Manajemen Kinerja Sumber Daya Manusia, Malang: Tunggal Mandiri Publishing.

Sugiyono, 2015, Metode penelitian pendidikan, pendekatan kuantitatif, kualitatif, dan R\&D, Bandung: Alfabeta.

Timpe A.D, 1989, The Art and Science of Bussiness Management Performance, New York: Kend Punishing. 